\title{
The Millennium Development Goals, Poverty Reduction and Future of Sub-Saharan Africa: A Prognostic Analysis
}

\author{
Chijioke Kelechi Iwuamadi \\ Institute for Development Studies, University of Nigeria, Enugu Campus, Enugu, Nigeria \\ Email: iwuamadikc@yahoo.com, chijioke.iwuamadi@unn.edu.ng
}

Received 8 April 2014; revised 20 May 2014; accepted 22 June 2014

Copyright (C) 2014 by author and OALib.

This work is licensed under the Creative Commons Attribution International License (CC BY). http://creativecommons.org/licenses/by/4.0/

(c) (i) Open Access

\section{Abstract}

The advent of the Millennium Development Goals (MDGs) coincided with a transition period from Structural Adjustment to Poverty Reduction Strategy Papers (PRSPs) and a general focus on Human Development. The paper critically reviewed extant literature on the MDGs as it affects Africa. The trend analysis shows that the state of MDGs in sub-Saharan Africa is worrisome especially as we are approaching the terminal 2015 expected year of achieving most of these goals. Based on this, the paper argues that, despite the persistent increase of external funds and aids targeted at making sure Africa achieves the MDGs, the region is yet to transform these gestures into tangible sustainable development. The paper examined the policy constraints and bottlenecks that frustrate achieving the MDGs. It also attempts to identify key areas where policy coherence and harmonization is required if progress towards MDGs achievements is to be accelerated. The paper further concludes that effective collaboration and commitment between governments and civil society and other relevant stakeholders is crucial and timely in creating the necessary synergy that will redefine the development priorities and strategies in a way that works for the majority of Africans.

\section{Keywords}

Millennium Development Goals, Poverty, Monitoring and Evaluation, Institutional Capacity, Sub-Saharan Africa, Oversea Development Assistance

Subject Areas: International Relations, Politics

In the Charter of the United Nations, countries pledged to work for "the promotion of the economic and social advancement of all peoples.” In the Universal Declaration of Human Rights, we recognized the inherent dignity and rights of every individual, including the right to a decent standard of living. And a decade ago, at the dawn of a new millennium, we set concrete goals to free our fellow men, women and children

How to cite this paper: Iwuamadi, C.K. (2014) The Millennium Development Goals, Poverty Reduction and Future of Sub-Saharan Africa: A Prognostic Analysis. Open Access Library Journal, 1: e610. http://dx.doi.org/10.4236/oalib.1100610 
from the injustice of extreme poverty. These are the standards we set. Today, we must ask-are we living up to our mutual responsibilities? (Barack Obama) [1].

\section{Introduction}

The concrete goals mentioned in President Obama's quote above refer to the Millennium Development Goals (MDGs). These MDGs emerged during the major international development summits of the 90s. The MDGs are 8 goals - to be achieved by 2015 - that aim to meet the greatest global challenges. They stem from the actions and targets contained in the Millennium Declaration, which was adopted by 189 nations and signed by 147 Heads of state during the Millennium Summit in September 2000. These 8 MDGs are associated with quantifiable targets and indicators. In the Millennium Declaration, Member States agreed that the MDGs cannot be achieved without effective public governance, transparent, accountable and participatory. Success will depend largely on the effectiveness of public administration and promotion of an innovative government working in partnership with all stakeholders. Each of these goals had clear targets to further enable countries develop their strategies for operations. Some of the socio-economic indices, although much improved, still remain far from the objective of meeting the internationally agreed millennium development goals (MDGs) targets. It is estimated that half of the population live in absolute poverty, while life expectancy and infant mortality is 52 years and 84 per 1000 live births respectively [2].

Compared to the other regions of the world, Africa and indeed, Nigeria stands to benefit from the lofty principles and goals of the Millennium Development Goals (MDG) initiated by world leaders and supported by the United Nations in 2000. In comparison to other industrialized countries, Nigeria, with its huge population, is one of the countries in Africa with the highest rates of child mortality, maternal mortality, HIV/AIDS, tuberculosis and malaria. The initiative also aims to narrow the yawning gap between developed and developing countries, ensuring equitable distribution and use of world's resources. The eight goals of MDGs can be summarized as follows [2]:

1) The eradication of extreme poverty and hunger: The target of this first goal is the reduction by half the proportion of people living on less than one dollar a day between 1999 and 2015. It also advocates the reduction by half the proportion of people living in extreme hunger.

2) Achievement of universal primary education; the goal has a set target of ensuring that by 2015, children everywhere, boys and girls, would have completed a full course of primary education.

3) Promotion of gender equality and the empowerment of women; the target is to eliminate gender disparity in primary and secondary education preferably by 2005, and at all levels of education by 2015. Indicators set for the attainment of this goal also aim at measuring progress towards ensuring that more women become literate, have a voice and representation in public policy and decision-making process, including improved job prospects.

4) The reduction of child mortality.

5) The improvement of maternal health.

6) Reduction of the incidence and prevalence of HIV/AIDS, malaria and other diseases; this goal has a target of reducing the spread of HIV/AIDS by half in 2015 and to subsequently witness the reversal of its spread.

7) Ensuring environmental sustainability; target is to sustain the environment by reducing the number of people without access to potable water by half in 2015, and also increases significantly or record improvement in the lives of at least 100 million slum dwellers by 2020 .

8) Development of a global partnership for development [2].

\section{Analysis of Africa's Recent MDG Performance (Culled from MDG Report of 2012) [3]}

A cursory look at Table 1 shows that the continent is quite off track as regards most of the MDGs. However, Africa's progress on the MDGs is gaining momentum. The continent continues to make somewhat steady progress on some of the goals. And even though it is unlikely to achieve all the targets by 2015, the rate of progress on several indicators - including primary school enrolment, gender parity in primary school enrolment, the proportion of seats held by women in national parliament, HIV/AIDS prevalence rates and the share of women in non-agricultural wage employment-is accelerating. Indeed, in some cases Africa exceeds regions such as South-eastern Asia, Latin America and the Caribbean, and Western Asia. This is both remarkable and commendable, though complacency must not be allowed to creep in. 
Table 1. Africa’s MDGs performance.

\begin{tabular}{|c|c|c|}
\hline $\begin{array}{l}\text { Goals and targets (from the } \\
\text { millennium declaration) }\end{array}$ & Status & Remarks \\
\hline $\begin{array}{l}\text { Goal 1: Eradicate extreme } \\
\text { poverty and hunger }\end{array}$ & Off track & $\begin{array}{l}\text { - } \quad \text { \$1.25-a-day poverty in Africa (excluding North Africa) } \\
\text { declined from } 56.5 \% \text { to } 47.5 \% \text { during } 1990-2008 \text {. }\end{array}$ \\
\hline $\begin{array}{l}\text { Goal 2: Achieve universal } \\
\text { primary education }\end{array}$ & On track: net enrolment & $\begin{array}{l}\text { - } \quad \text { Average enrolment exceeds } 80 \% \text {. } \\
\text { - } \quad \text { Issues of quality remain. } \\
\text { - } \quad \text { Most countries are not expected to meet the completion target. }\end{array}$ \\
\hline $\begin{array}{l}\text { Goal 3: Promote gender equality } \\
\text { and empower women }\end{array}$ & On track & $\begin{array}{l}\text { - Good progress at primary level but weak parity at } \\
\text { - } \quad \text { High representation in parliament. }\end{array}$ \\
\hline Goal 4: Reduce child mortality & Off track & - Declining, but slowly. \\
\hline Goal 5: Improve maternal health & Off track & - Declining, but slowly. \\
\hline $\begin{array}{l}\text { Goal 6: Combat HIV/AIDS, } \\
\text { malaria and other diseases }\end{array}$ & Off track & $\begin{array}{l}\text { - HIV/AIDS on the decline, especially in Southern Africa, } \\
\text { due to behavioural change and access to antiretroviral therapy. }\end{array}$ \\
\hline Goal 7 & $\begin{array}{l}\text { Ensure environmental } \\
\text { sustainability on track: improved } \\
\text { water supply }\end{array}$ & $\begin{array}{l}\text { - } \quad \text { Few countries have reforestation plans. } \\
\text { - } \quad \text { Emissions minimal for most countries with little increase. } \\
\text { - } \quad \text { Substances by more than } 50 \% \text {. }\end{array}$ \\
\hline
\end{tabular}

Source: Computations from UNSD, accessed December 2011, cited in MDG 2012 Report.

\subsection{Poverty Is Declining Slowly and Decent Jobs Are Hard to Find}

Both the rate of poverty and the absolute number of poor in Africa declined during 1990-2008. Excluding North Africa, the rate of poverty in Africa fell from 56.5 per cent to 47.5 per cent, driven in part by strong economic growth of the past decade and a decline in the proportion of workers below the poverty line (\$1.25 a day). Nevertheless, decent jobs are at a premium in Africa as the majority of jobs are in the informal sector, which generally has low incomes, low productivity and poor working conditions. Vulnerable employment accounts for some 70 per cent of employment growth—and is largely overrepresented by women.

\subsection{Food Price Increases Are a Barrier to Reducing Malnutrition}

The proportion of children under five who are malnourished in Africa (excluding North Africa) declined only marginally, between 1990 and 2009, despite a reduction in the poverty rate. Contributing to the sluggish decline was the continued escalation in food prices, which has invariably had an adverse impact, particularly on the food budgets of lower-income groups. Girls and rural dwellers are the most affected.

\subsection{More Children Are in Primary School, but Retaining Them Requires More Effort}

Net primary enrolment in most African countries shows tremendous gains, with ratios exceeding 90 per cent in several countries. Completion rates, however, have seen little progress, and are as low as 33 per cent in some countries. Predictably, dropout rates are higher among girls than boys. Teacher absenteeism, late age entry by children in primary school cycles, poor health and nutritional status of pupils, financial constraints, distance to school and quality of educational facilities are some of the factors affecting educational quality and completion rates.

\subsection{Gender Parity and Women's Empowerment-A Glass Half Full}

African countries have made significant strides in promoting gender parity in primary education. But they need to do more at secondary and tertiary levels to fully exploit women's intellectual capacities. And although gender parity in paid non-agricultural employment is observed in the services sector (where women usually outnumber men), the reverse is true for higher-paying industrial jobs, which may stoke gender wage disparities because 
wages differ across sectors, skills and occupations. In politics, Africa needs to move beyond women's participation to improving their capacity for contributing to development discussions and outcomes.

\subsection{Lagging Health Indicators}

Performance on health indicators such as infant, under-five and maternal mortality is still improving but not fast enough to achieve the goals. Immunization coverage, in contrast, has expanded rapidly and only two countries record less than 50 per cent coverage.

\subsection{Access to Contraceptives Is Reducing Maternal Deaths}

Progress in reducing maternal deaths stems largely from declining fertility rates, helped by greater access to contraceptives. Yet almost one in four women in Africa who wish to space or delay their next pregnancy cannot do so because of lack of access to contraceptives, failure to empower women to use contraceptives and a mismatch between the types of contraceptives desired and those provided.

\subsection{Funding Cuts Threaten Progress on the HIV/AIDS Front}

Africa appears to be starting to win the battle against HIV/AIDS. This is evidenced by a fall in the prevalence rate (particularly among women), a steep decline in the regional rate of new infections (the incidence rate), a reduction in the number of AIDS-related deaths and a drop in mother-to-child transmission of HIV/AIDS. Behavioural change and access to antiretroviral therapy (ART) have underpinned the HIV/AIDS turnaround in Africa. Sustaining access to ART in an uncertain funding environment will, however, present a challenge to the countries most affected by the disease. Indeed, the announced cancellation of Round 11 of the Global Fund to Fight AIDS, Tuberculosis and Malaria (the Global Fund) could lead to reversals in other vertical funding schemes.

\subsection{Malaria-Related Deaths Are Down but Access to Effective Drugs Is Limited}

Malaria mortality rates in Africa have declined by more than a third since 2000 owing to increased prevention and control measures. But the most effective treatment regimens-artemisinin-based combination therapiesstill account for only a tiny portion of total treatment.

\subsection{Environmental Challenges Persist}

Poor sanitation, limited access to improved drinking water sources and declining forest cover are among the most pressing environmental challenges facing the continent-and climate change is likely to make them worse. But more positively, carbon dioxide $\left(\mathrm{CO}_{2}\right)$ emissions have stabilized in most African countries, and the majority of countries have lowered their consumption of ozone-depleting substances. Furthermore, twenty-seven countries have listed improvements in the share of protected terrestrial and marine areas.

Excerpts from MDG 2012 Report on Africa: Summary of Collective Views of Jean Ping, Chairperson, African Union Commission, Abdoulie Janneh, Executive Secretary, Economic Commission for Africa, Donald Kaberuka. President, African Development Bank Group, Helen Clark, Administrator, United Nations Development Programme.

The findings of 2012 MDG report on Africa confirm that steady economic growth and improvements in poverty reduction on the continent continue to have a positive impact on MDG progress. Africa has sustained progress toward several MDGs and is on track to achieve the targets of: universal primary education; gender parity at all levels of education; lower HIV/AIDS prevalence among 15 - 24 year olds; increased proportion of the population with access to antiretroviral drugs; and increased proportion of seats held by women in national parliament by 2015. Even so, the report acknowledges that more needs to be done to address inequalities, including between women and men. It highlights the need to address the sub-standard quality and unequal distribution of social services between rural and urban areas. It suggests active steps to ensure that economic growth translates into new and adequate employment opportunities for Africa's youthful and rapidly growing population, and social protection systems which grow the resilience and capabilities of poor and vulnerable households. The report urges policymakers to put greater emphasis on improving the quality of social services and ensuring that investments yield improved outcomes for the poor. Expanding access and improving the quality of social services are both imperative for MDG progress. A balance must be struck to move both objectives forward. The 
report observes that high rates of population growth can strain countries' ability to deliver vital public services and undercut progress. Africa needs to turn this dynamic on its head, to exploit a "demographic dividend" which can help drive growth, innovation, and provide a clear competitive advantage. To do this the countries of Africa must invest in their greatest asset, their people —in particular, their growing number of young people —ensuring that they can be the productive, innovative, and engaged citizens who will help accelerate MDG progress and achieve sustainable human development [3].

\section{Countdown to 2015 MDG Target Year}

With only about 18 months to the target date of 2015, the paper attempts to examine the factors that have shaped MDG progress in Africa in recent years. We observed that there are bottlenecks and constraints that have slowed progress, which apparently requires that existing policies should be changed or modified to make the achievement of the MDGs at all levels a reality. In 2011, the World Bank reported that only four African countries are likely to achieve the Millennium Development Goals (MDGs) by 2015. The report attributed this to accelerated growth and progress on social indicators in these countries. The four countries (Cape Verde, Ethiopia, Ghana, and Malawi) will likely achieve most of the Millennium Development Goals by 2015 or soon thereafter. The report further observed that up till date, about half of the population in Africa lives on 1.25 dollar per day adding that government remained weak. It added that about 645 women die during pregnancy and child birth per 100,000 life birth. The report also observed that conditions were improving in Africa as maternal mortality has declined by 26 percent between 1990 and 2009. "Child mortality rates are also declining, the rate of HIV infection is stabilising, Primary school completion rate is rising faster than anywhere else in the world and the percentage of people living in extreme poverty is falling" [4].

Meanwhile, with less than three years out of fifteen for reaching the targets and indicators of the MDGs having been passed with little or no much success, all hands must be on deck to ensure that Africa and Nigeria in particular does not fail. The Monitoring and Evaluation process of Nigeria's MDG expenditures for 2006 show that:

Unfortunately however, the overall level of implementation of the various 2006 programmes on the whole, fell below expectation. Several of the 2006 DRG funded projects and programmes remained at different stages of completion as at December, 2007. Many had not started at all [5].

Furthermore, the data also indicates that:

The quality of delivery of work on the projects was also, in most cases, unsatisfactory. In spite of all problems associated with the implementation, there was near unanimity among beneficiaries that many of the DRG projects and programmes had great potential in addressing their development challenges even though they were not consulted at the planning stage [5].

A valid question is whether Africa (Nigeria) can afford to fail in achieving the MDGs by 2015? We cannot continue to allow the persistence of, poverty, hunger, maternal mortality etc in our society.

What are the possibilities we need to explore to achieve the MDGs? What are the challenges of achieving the Millennium Development Goals in Nigeria? They include the following:

1) Ensuring that economic policy reforms are directed not only at promoting economic growth but also at social expenditures that will keep us on track in achieving the MDGs.

2) Monitoring of the budgets at national, state and local government levels to keep social expenditures on track.

3) Enhancing research capacity to improve our capacity to use natural and social sciences as well as technology in attaining the MDGs

4) Developing more effective advocacy tools and strategies by civil society and communities to keep our governments and the international community on the right track.

\section{MDGs and Poverty in Africa (2001-2014)}

Analyses of the MDG 2012 Africa Report reveals that Poverty is on a slow decline in Africa and is unlikely to meet the target Based on the World Bank's poverty estimates for 2008, the developing world was very close to reaching the global target of halving income poverty by 2015. Despite the deleterious effects of the triple crises 
of fuel, food and finance, the overall share of the developing world's population living on less than $\$ 1.25$ a day in 2008 was 22 per cent, just about 0.4 percentage points above the 2015 target of 21.6 per cent. This translates into 1.29 billion people in 2008 who lived on less than $\$ 1.25$ a day, compared with 1.91 billion in 1990 . This is the first time, since 1981, that both the poverty rate and the number of poor in all six regions of the developing world declined at the same time. This success can be linked to the dramatic progress in populous countries like China, Indonesia and Brazil. Like the other regions, Africa also experienced a decline in the poverty rate as well as the absolute number of poor people. However, its rate of decline in poverty is too slow to achieve the target by 2015. For instance, the proportion of people living on less than $\$ 1.25$ a day in Africa (excluding North Africa) decreased marginally from 56.5 per cent in 1990 to 52.3 per cent in 2005 and further to 47.5 per cent in 2008. Only East Asia and the Pacific, and the Middle East and North Africa have reached the target [3].

The report further observed that Poverty in Africa is concentrated in rural areas and affects men and women differently Poverty in Africa is spatial, with a higher prevalence of rural poverty. All 37 countries with data for this indicator exhibit a wide disparity between urban and rural poverty. Rural poverty is at least three times as high as urban poverty in Morocco, Egypt, Ghana, Zambia, Cameroon, Cape Verde and Rwanda. Poverty is declining slowly in Africa according to same report. Several factors may account for this. Women's work in the home often prevents them from having wage employment. And when they do earn wages, their work tends to be undervalued. Women work mostly in low-wage jobs and in poor conditions. Restricted access to economic resources and lack of education are also important in feminizing poverty.

On the other hand, the high level of poverty and youth unemployment constitutes fundamental development challenges facing the nation. In terms of human capital, Nigeria is one of the countries in the global south that exported the largest number of highly educated migrants, thereby losing its skilled workers and obviously creating adverse effects on productivity and economic growth. Inadequate funding and high level of corrupt practices in public institutions has hindered effective take-off of the MDGs in many states and sectors ${ }^{1}$.

Prior to the global financial/economic crisis, over three quarters of workers in Oceania, Southern Asia and sub-Saharan Africa were without the security that wage and salaried jobs could provide. The crisis is likely to have further increased the number of workers engaged in vulnerable employment in these regions in 2009. The International Labour Organization (ILO) estimates the global vulnerable employment rate in 2009 to be between 49 per cent and 53 per cent, which translates into 1.5 billion to 1.6 billion people who are working on their own or as unpaid family workers worldwide. Since the economic crisis, more workers find themselves and their families living in extreme poverty (Figure 1).

\section{Proportion of Employed People Living below \$1.25 a Day, 1998, 2008 and 2009 (Percentage)}

The largest negative impact is most likely to be seen in sub-Saharan Africa, Southern Asia, South-Eastern Asia and Oceania, where extreme poverty among the employed may have increased by four percentage points or more in the second scenario. These estimates reflect the fact that, prior to the crisis, many workers in these regions were only slightly above the poverty line. In the case of sub-Saharan Africa, the large majority of workers (63.5 per cent) were at risk of falling below the extreme poverty line in this scenario [6].

The global financial crisis also led to decline in exports from Africa in 2008, decline in remittances to Africa, more people living in extreme poverty by end of 2010, out of 650 million the number of African's living below US \$1.25 per day, out of 163 million, the number of Africans who are ultra poor in 2005 [7]. We recall that late

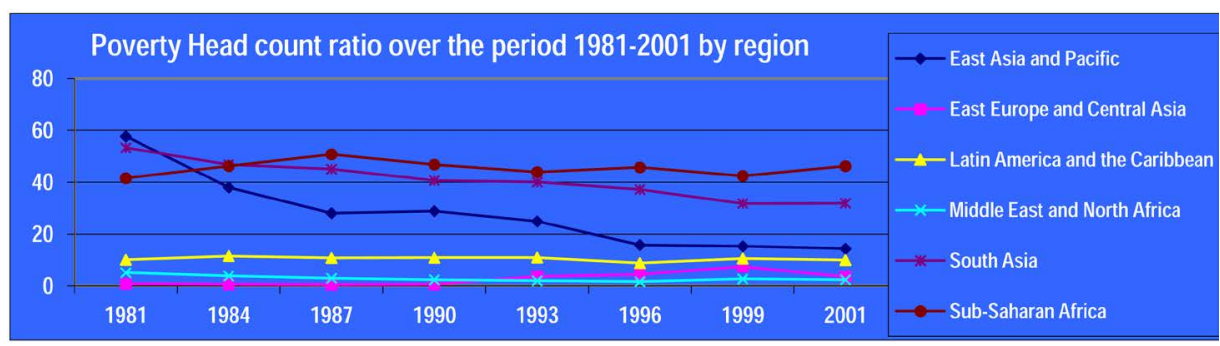

Figure 1. Trends of poverty: SSA and rest of the world.

${ }^{1}$ Statement by Jibrin Ibrahim (2014) Immediate Past Director of Center for Democracy and Development. 
President Umaru Musa Yar'Adua of Nigeria in his campaign manifesto entitled, End Poverty, Develop Nigeria, promised Nigerians that "the United Nations Millennium Development Goals is our guide" and committed himself to "confront poverty and develop Nigeria" if elected into office. Consequently, Wealth Creation and Poverty Alleviation became number three in his seven point agenda then [8].

A more recent data reveals that many countries of the world especially in Africa, including Nigeria continue to formulate and implement policies and programmes that further widen the gap instead of closing the gap between rich and poor nations on the one hand and rich and poor citizens of individual countries on the other. Part of the problem is that the dominant knowledge in the world promoted by the dominant classes naturally lead to widening of the gap. Consequently, despite the apparent robust economic growth rates achieved in the Nigerian economy since the signing of the Millennium Declaration, the impact on reducing poverty and hunger in the country remains dismal. A key challenge is how to formulate and implement concrete, practical and workable policies at the three levels of governance in the country to successfully address the dysfunctional growth-employment-poverty reduction nexus in the country and close the widening poverty gap [9].

\section{The State of MDGs in Sub-Saharan Africa (SSA): The Case of Nigeria}

\subsection{Why Nigeria?}

The MDG Report 2013 emphasizes that progress for all children in sub-Saharan Africa is "within our grasp." The region doubled its average rate of reduction of child deaths from 1.5 per cent a year in 1990-2000 to 3.1 per cent a year in 2000-2011, although it still has the highest child mortality rate in the world. From 1990 to 2011 for children under age five, the mortality rate dropped by 39 per cent (from 178 deaths per 1000 live births to 109) and the proportion of those who are underweight dropped from 29 to 21 per cent. Some countries with high under-five death rates, including Ethiopia, Liberia, Madagascar, Malawi, Niger and Rwanda, reported reductions of at least 60 per cent [10].

For African countries as a whole, the prevalence of undernourishment fell from 27.3 to 22.9 per cent over the period 1990-2010. However, the rate of improvement was very slow (16.1 per cent) as compared to other regions of the world except Oceania (11 per cent). Ghana (87.6 per cent), Djibouti (70.9 per cent), Mali (68.8 per cent), the Niger and Sao Tome and Principe (65.9 per cent) were the best-performing countries during the period 1991-2011. However, the prevalence of undernourishment worsened in 102 African countries during the same period [11]. In terms of enrolment into primary education, although progress has been positive across the continent, the pace of progress varied widely across countries. Worthy of note is that the Niger increased its enrolment from 53 to 62 per cent between 2009 and 2011, while Ghana and Mali increased their enrolment rates from 77 to 84 per cent and 64 to 67 per cent respectively during the same period [12].

Looking at the oversea development assistance (ODA) total ODA to all landlocked developing countries (LLDCs) increased by only 2 per cent between 2009 and 2010. Lesotho, Malawi and the Niger experienced the highest increases, while Botswana, Chad, Ethiopia, Uganda, Zambia and Zimbabwe suffered declines [13]. LLDCs face unique challenges that constrain their economic growth and development. Rising world crude oil prices and reliance on ports of entry in other countries highlight the importance of effective intergovernmental coordination for LLDCs. Regional integration and trade facilitation are also increasingly becoming important in this context [14].

Africa still bears the largest burden of maternal deaths in the world, with over 50 per cent of the global maternal deaths occurring on the continent. At 429 deaths per 100,000 live births, Africa lags behind developing regions as a whole (240), Southern Asia (220) and the Caribbean (190). In fact, the 10 highest MMR countries10 are in Africa, and an estimated 14 per cent of maternal deaths globally occur in Nigeria [13]. It is important to note that four countries (Central African Republic, Gabon, Kenya and Zambia) have made no progress, while nine (Botswana, Cameroon, Chad, Congo, Lesotho, Somalia, South Africa, Swaziland and Zimbabwe) registered an increase in MMR during the period 1990-2010 [15].

Therefore, part of the reason for choosing Nigeria as primary case study in this paper is basically because of her "big brother" role in the continent and her "self-acclaimed" giant of Africa and more importantly the largest re-based economy in Africa. However, the theoretical basis of selecting Nigeria is not far from the internal huge investment of at least an annual one billion naira set out for MDGs. This for me is far much above what other countries invest in MDGs excluding the external supports they get from development partners. Another important reason is that unlike most countries of Africa, there is the five-year Countdown Strategy of Nigeria's un- 
flagging determination to achieve the Millennium Development Goals. This strategy is produced with an acute awareness of the short amount of time that is left to achieve the lofty objectives of the 2015 deadline, this document is therefore squarely focused on clarifying Nigeria's current position with a view to putting measures in place to ensure accelerated progress.

According to Amina Az-Zubair ${ }^{2}$, the advantage we have is that the MDGs are not new to Nigeria. They are essentially a scaled-up version of policies and investments that Nigeria has been putting in place for decades. In this context, the specific targets, international collaboration and clear timelines associated with the MDGs have provided an invaluable reference point for ensuring that our efforts are redoubled and continuously scrutinised. She further expressed that the Countdown Strategy has been designed to identify the gaps and lay out the policy actions, investments, and milestones that will help us further scale up our successes and remedy our weaknesses. It provides a road map to achieving the MDGs, drawing on this administration's direct engagement with issues such as improving service delivery and public accountability, increasing investment, and building partnerships across the three tiers of government. In particular, it will be the reference point for any new administration, so ensuring that the opportunity to renew momentum provided by such a transition is seized rather than wasted. The Countdown Strategy will also guide the institutional improvements, policies and human resources required to meet the MDGs, chart the trajectory of MDGs financing and investment to 2015, and interface with the country's Vision 20:2020 and the 7-Point Agenda. For the Nigeria government, for the MDGs to be achieved on time, massive pro-poor investments will have to be made across all sectors.

With less than 18months to 2015, the MDGs target year, Nigeria has made relative progress in her efforts to achieve the various targets. The decision to channel the resources from the debt relief gains into MDGs projects and programmes in 2005 provided much needed resources to enable the government to take bold steps towards to identify with MDGs processes and also, more importantly, try to mainstream MDGS policies into its on-going development plans. Government's attempts to capture MDGs interventions in its key government planning and strategy documents, including NEEDS, SEEDS, LEEDS, Vision 20:2020 and the Transformation Agenda, have achieved some progress. However, despite these progress, the analyses carried in this study reveals that some of the goals and targets are likely to be missed unless additional, strengthened or corrective policy action is taken urgently [16].

Rapid progress in achieving the MDGS will require coherence in federal, state and local policies as well harmonization between and among them. It would require coherence in the setting of priorities and in the financing MDGs-related interventions. It would also require coherence between interventions designed to manage shortterm emergency situations and longer-term development goals. Six action areas which should receive attention to accelerate the achievement of the MDGs as the country approaches 2015 are outlined below [16]:

1) Vision 2020: From Visioning to Implementation: Nigeria stepped up its efforts to achieve the MDGs with the launching of Vision 2020 in 2009 as the country's blueprint for economic transformation. The expected outcome of the policy is a high standard of living and quality of life for its citizens. To achieve this, the policy framework attempts to prioritise economic growth and job creation over the next seven years. The MDG goals have been incorporated into the visioning process but the key challenge is that there is very little being done on the implementation of the policy package. The level of investment on infrastructure and job creation is insufficient to push the country to the desired goal of being part of the top twenty economies in the world. There is, therefore, need to invest more to meet the explicit targets for access to energy and transportation, provide key inputs to economic development that are deeply important for agricultural productivity, health, education, and other key Goals. This area typically requires a strong blend of partnership between public and private sectors, on both the investment side and the regulatory side, in order to ensure efficient operations with equitable access for poor people. The public sector must however take the lead if the country is to achieve the targets and policy- and decision-makers must develop clear benchmarks for implementing the visioning process. Public budgeting processes must also become more closely aligned to the Vision 2020 implementation benchmarks.

2) Combating Public Corruption: Over time, there has been increasing evidence of the growth of mega corruption in Nigeria. Revelations over the past year relating to the petroleum subsidy reveal monumental and growing level of fraud in public life in which over one trillion naira has been looted so far. Corruption has therefore become a stumbling block to combating poverty and achieving the MDGs. In addition to fuel subsidy, the country has been witness to the recent police pension scam and the unbelievable spectacle in the House of Representatives investigations on the power probe where it was discovered that over \$16 bn was spent to pro-

${ }^{2}$ Amina Az-Zubair is the Immediate Past Senior Special Assistant to the Nigeria President on MDGs. 
vide electric power without commensurate results. Government is currently negotiating a \$1.5 trillion loan to pay more fuel "subsidy". Nigeria is suffering from a pattern of organised looting of our national resources emanating from governments. If Nigerians do not stand up to fight and hold their leaders accountable for their actions, the county's prospects for development will remain mortgaged to poor governance. The spectacular failure of recent high profile criminal prosecutions relating to corruption dramatizes the collapse of the system of public prosecution in Nigeria. Public prosecution rests on a tripod-the detection and investigation of crime, the prosecution of offenders and the conviction and punishment. All levels are in crisis and for Nigeria to return to its development agenda and implementation of Vision 2020, the promotion of transparency and accountability in public life must become a priority. There is increasing evidence that Government will not act on anti-corruption if citizens do not mount sufficient pressure. Nigeria belongs to all its citizens they can no longer leave the political space and bureaucracy to shenanigans, and for common thieves and crooks. The fight against corruption must be comprehensive and all encompassing. All sections of the society must stand up and fight corruption as part of the collective strategy of liberating the resources to implement Vision 2020.

3) Addressing the Insecurity/Poverty Nexus: Nigeria has several sources of instability. The Niger Delta amnesty remains fragile. Ethno-religious conflict in the "middle belt" with its epi-centre in Plateau state continues to grow. An Islamist insurgency in Nigeria's north-east is spreading to other parts of the country. Banditry and kidnapping is making the south-eastern and south-southern parts of the country difficult to live in. These conflicts are fuelled at the national level by deepening poverty, an expanding demography as well as ethnic, religious, social and economic grievances. These grievances point to a crisis of democratic consolidation in which citizens are not seeing the dividends of the democratic transition that occurred in 1999. The reality is that the Nigerian state is undergoing a serious existential crisis.

Nigeria has been rapidly urbanising at an incredible rate. The urban centres are focal points for the globalisation of the economy, society and religion, while shanty towns and their lumpen culture are the flash-points. Life is becoming increasingly precarious because of the breakdown of social fabric and family bonds as well as the mounting pressures on livelihoods. In these contexts, religious activities have proliferated, with both Muslim and Christian actors and movements stepping in to provide critical services that the family and the state are unable to provide. Most of the new religious actors operate in the field of popular religion and act autonomously with little or no supervision from the state of religious establishments. The counterfactual message from this analysis is that if achieving the MDGs had been prioritized as a strategy for national survival and progress, the country would not have found itself in the present situation. The urgent message form this is that addressing poverty and misery is a vital component of the country's national security strategy but even more importantly, it is a fulfilment of the pact signed by Nigerians and their governments to achieve the social and economic goals set out in chapter two of the country's Constitution.

4) Climate change and its attendant effects on livelihoods: Nigeria is one of the tropical countries with the largest forest losses in the world. The country is experiencing an annual rate of deforestation of about 3.5\%, resulting from illegal and uncontrolled logging, incessant and uncontrolled bush burning, overgrazing and unsustainable fuel wood gathering. The rich biodiversity of the forests remains imperiled by the high rate of deforestation and degradation not minding that forests play an important role in the global carbon cycle. Currently, forests in Nigeria occupy about 10 million ha $(100,000 \mathrm{sq} / \mathrm{km})$, close to 10 percent of Nigeria's initial forest land area and well below the Food and Agriculture Organization's recommended national minimum of 25 percent. From 2000-2010, the area of forest reduced by one third, from $14.4 \%$ in 2000 to $9.93 \%$ of its land mass in 2010 . The desert in the Sahara continues to encroach southwards at a rather unprecedented rate of $0.6 \mathrm{~km}$ per year, causing the country to be losing 1355 square miles of cropland and rangeland due to desertification each year.

Elsewhere, the effects of global greenhouse gas continue to rise, causing dramatic changes in temperature, and precipitation. The impact of this on Nigeria has been dramatic in the last two years as floods and erosion continue to pose threats to human and food security and causing environmental degradation in alarming magnitudes in different parts of the country. Between 2010 and August 2012 alone, over a million people have been displaced by erosion and flooding in several parts of the country. These have led to the contamination of unprotected water sources, thereby exposing people to the risk of waterborne diseases; destruction of crops and disruption of the planting season. As Nigeria approaches 2015, there is an urgent need for the implementation of policies and programmes aimed at addressing the challenges of climate change.

5) Addressing the Insecurity/Poverty Nexus: Nigeria has several sources of instability. The Niger Delta amnesty remains fragile. Ethno-religious conflict in the "middle belt" with its epi-centre in Plateau state continues 
to grow. An Islamist insurgency in Nigeria's north-east is spreading to other parts of the country. Banditry and kidnapping is making the south-eastern and south-southern parts of the country difficult to live in. These conflicts are fuelled at the national level by deepening poverty, an expanding demography as well as ethnic, religious, social and economic grievances. These grievances point to a crisis of democratic consolidation in which citizens are not seeing the dividends of the democratic transition that occurred in 1999. The reality is that the Nigerian state is undergoing a serious existential crisis. Nigeria has been rapidly urbanising at an incredible rate. The urban centres are focal points for the globalisation of the economy, society and religion, while shanty towns and their lumpen culture are the flash-points. Life is becoming increasingly precarious because of the breakdown of social fabric and family bonds as well as the mounting pressures on livelihoods. In these contexts, religious activities have proliferated, with both Muslim and Christian actors and movements stepping in to provide critical services that the family and the state are unable to provide. Most of the new religious actors operate in the field of popular religion and act autonomously with little or no supervision from the state of religious establishments. The counterfactual message from this analysis is that if achieving the MDGs had been prioritized as a strategy for national survival and progress, the country would not have found itself in the present situation. The urgent message form this is that addressing poverty and misery is a vital component of the country's national security strategy but even more importantly, it is a fulfilment of the pact signed by Nigerians and their governments to achieve the social and economic goals set out in chapter two of the country's Constitution.

6) Climate change and its attendant effects on livelihoods: Nigeria is one of the tropical countries with the largest forest losses in the world. The country is experiencing an annual rate of deforestation of about 3.5\%, resulting from illegal and uncontrolled logging, incessant and uncontrolled bush burning, overgrazing and unsustainable fuel wood gathering. The rich biodiversity of the forests remains imperiled by the high rate of deforestation and degradation not minding that forests play an important role in the global carbon cycle. Currently, forests in Nigeria occupy about 10 million ha $(100,000 \mathrm{sq} / \mathrm{km})$, close to 10 percent of Nigeria's initial forest land area and well below the Food and Agriculture Organization's recommended national minimum of 25 percent. From 2000-2010, the area of forest reduced by one third, from $14.4 \%$ in 2000 to $9.93 \%$ of its land mass in 2010 . The desert in the Sahara continues to encroach southwards at a rather unprecedented rate of $0.6 \mathrm{~km}$ per year, causing the country to be losing 1355 square miles of cropland and rangeland due to desertification each year.

Elsewhere, the effects of global greenhouse gas continue to rise, causing dramatic changes in temperature, and precipitation. The impact of this on Nigeria has been dramatic in the last two years as floods and erosion continue to pose threats to human and food security and causing environmental degradation in alarming magnitudes in different parts of the country. Between 2010 and August 2012 alone, over a million people have been displaced by erosion and flooding in several parts of the country. These have led to the contamination of unprotected water sources, thereby exposing people to the risk of waterborne diseases; destruction of crops and disruption of the planting season. As Nigeria approaches 2015, there is an urgent need for the implementation of policies and programmes aimed at addressing the challenges of climate change.

On the other hand, Nigeria is one of the countries that got debt cancellation but funds directed towards achieving these set goals and targets. As far back as 2000, the Nigerian government was also among 188 other governments across the world that made the millennium declaration containing the Millennium Development Goals (MDGs) committing to eradicating poverty and injustice in the world. In Nigeria, one major failure in the economic reform agenda is making an impact on poverty alleviation. Government at all levels in Nigeria have not properly addressed the issue of poverty and thereby condemning the majority of Nigerians to a life of misery [17]. Less than three years into the MDGs time frame, this is what the situation is in Nigeria:

- More than $54 \%$ of Nigerians live below $\$ 1$ (N160) a day.

- More than $6.8 \mathrm{~m}$ Nigerian children of primary school age are out of school.

- Net enrolment for girls in primary and secondary school in the north is $34 \%$ and $10 \%$ respectively.

- More than 197 out of every 1000 Nigerian babies die before they are 5 years old.

- An estimated 800 Nigerian women die for every 100,000 live births.

- There were 300,000 deaths related to HIV in 2003/2004. It is estimated that more than $70 \mathrm{~m}$ Nigerians have one episode of malaria annually.

- It is estimated that Nigeria is currently losing about more than $350 \mathrm{sq} \mathrm{km}$ to desert encroachment annually

- Globally there is a challenge of fair trade especially between the developed countries and the emerging economies, mostly poor countries.

It is estimated that in order to achieve the MDGs in Nigeria by the year 2015, $\$ 5$ billion to $\$ 7$ billion must be channeled to MDG programmes per annum. The government is presently allocating about $\$ 1$ billion annually 
out of which $\$ 750$ million is by the Federal Government and about $\$ 250$ million by state governments. The numbers do not match and it is clear that the public expenditure levels by the three tiers of government are not sufficient to meet the MDGs as demonstrated in the Nigeria MDG report 2006 [17]. The report shows that at the present rate, the only MDGs we have the potential to meet by 2015 are:

1) Achieving universal primary education.

2) Combating HIV/AIDS.

3) Ensuring environmental stability.

4) Developing a global partnership for development.

Even these four are highly problematic. Enrolment in primary education is certainly growing at a high rate. However, the quality of teachers is not improving significantly, especially in the North and the schools are not well equipped. Indeed, in some Northern states, growing enrolment is proceeding with growing illiteracy.

The admission in the 2006 Report that we might meet four of the MDGs is disturbing. It means that we are not on course to meet the key MDGs that are the most critical:

1) Eradicating extreme poverty and hunger in spite of the fact that 69 million Nigerians are affected.

2) Achieving gender equality in our primary schools and empowering women.

3) Reducing child mortality with under-5 mortality for 2005 being 197 for every 1000 live births.

4) Improving maternal healthcare given our mortality rate of 800 for every 100,000 live births.

There is an urgent need for a major policy summersault to get us back on the road map to achieving the MDGs by 2015. We need a policy shift that would prioritize and significantly increase social expenditure and include the poor in public budgeting [17]. This is considering the fact that other options like domestic self-help has failed in recent past, thereby suggesting for a more radical approach towards investment opportunities that will attract national and international corporate entities. As a response to this call, Nigeria's Countdown Strategy during Yaradua's regime outlines the country's roadmap for achieving the Millennium Development Goals (MDGs) by 2015. It identifies the mechanisms and interventions that have been most effective to date, and emphasizes the need for stronger partnerships with key stakeholders. It also underlines the constitutional roles and responsibilities of state and local governments in achieving the MDGs. In addition, the strategy provides a guide for the institutional improvements, policy reforms and human resources required for progress on the MDGs, while charting the trajectory of MDG financing and investment to 2015. Finally, it spells out focused strategies for scaling up the implementation of interventions that will accelerate progress on the eight MDGs:

\subsection{Re-Examining Investment}

Using a recent study of MDGs investments across the three tiers of government, the Countdown Strategy proposes a new financing strategy that emphasizes the need for the three tiers of Nigeria's government, the three arms of government and other stakeholders, to make solid commitments over the next five years through a national partnership and fiscal compact for the MDGs.

To help with this, the Strategy provides a roadmap of actions and responsibilities, as well as a timeline. It focuses particularly on improving coordination, and monitoring \& evaluation (M \& E).

This roadmap provides guidance to the new administration expected in 2011, but also makes room for flexibility for any refinements or modifications that may be introduced.

\subsection{Scaling-Up Opportunities}

The opportunities to scale-up investments and policies provided by debt relief have contributed immensely to the modest progress recorded so far. Many promising and best practice interventions and initiatives have been adopted by the Nigerian government in order to achieve the MDGs.

The Results-based Monitoring and Evaluation Framework makes use of independent civil society. And, the Midwives Service Scheme has deployed thousands of midwives to rural areas. Similarly, the Federal Teachers' Scheme aims to recruit an additional 80,000 teachers every two years. Social protection has also been expanded, including Conditional Cash Transfers to vulnerable households. The MDGs Conditional Grants Scheme has scaled up investments by state and local governments by over US $\$ 800$ million (N120 billion).

In addition, the Universal Basic Education fund has helped to increase enrolment rates, while the Community Health Insurance Scheme provides free basic healthcare to pregnant mothers and children. The Rollback Malaria partnership with the Strategies for achieving the MDGs: Four strategic imperatives are critical to accelerating 
Nigeria's achievement of the MDGs by 2015:

- Improving the governance and accountability environment.

- Strengthening coordination and cooperation among the three tiers and arms of government.

- Mobilising and committing all communities and key stakeholders to the MDGs.

- Ensuring effective mainstreaming of MDGs into overall national and sub-national development visions and plans.

\subsection{Identifying the Funding Gap}

A recent analysis of public expenditure allocations on the MDGs by federal and state governments and local government authorities (LGAs) has suggested that the annual funding gap may be as high as US \$17.7 billion. Therefore, a major challenge remains in scaling-up funding for the MDGs at the local level. The MDGs Needs Assessment and Financing Strategy for Nigeria had projected that the local governments would contribute some 17.5 per cent of the total public sector funding of MDGs in the period 2009-2010. Clearly, therefore, there is a need for local government to continue to prioritize spending on the MDGs from 2010 onwards.

\section{Key Strategies for Achieving the MDGs in Nigeria}

In Table 2, some specific strategies were explained in details that will likely accelerate achievement of the MDGs, meanwhile the following four strategic imperatives are critical to accelerating Nigeria's achievement of the MDGs by 2015:

- Improving the governance and accountability environment.

- Strengthening coordination and cooperation among the three tiers and arms of government.

- Mobilizing and committing all communities and key stakeholders to the MDGs.

- Ensuring effective mainstreaming of MDGs into overall national and sub-national development visions and plans.

Specific strategies for accelerating progress towards achieving the MDGs-lessons that other African countries can draw from Nigeria [18].

\section{Nigeria's Success Story: The Conditional Grants Scheme}

The Conditional Grants Scheme (CGS), introduced in 2007, has three specific objectives: 1) to invest in achieving the MDGs at the sub-national level and ensure local ownership and sustainability; 2) to empower state and local governments to carry out their constitutional responsibilities; and 3) to leverage public sector reform, public expenditure reform and national planning for service delivery. According to an independent evaluation (SPARC 2010) of the programmes and projects financed in 2007 and 2008, the CGS has been very successful: 98 per cent completion rates were achieved for projects and programmes financed with CGS awards in 2007, and 88 per cent completion rates were achieved for projects and programmes financed with CGS awards in 2008. In 2007 and 2008 most projects focused on health, water and sanitation, and economic activities. The 2009 CGS projects and programmes are still at various stages of implementation. The estimated number of beneficiaries 2007-2009 ranged from about 500,000 for economic projects to over 30 million for health projects, and over 8 million for water and sanitation projects [19]. Furthermore, an independent assessment (SPARC 2010) of a sample of states that benefitted from CGS awards between 2007 and 2009 showed that the objectives of the CGS have largely been met [20].

\section{Is Africa Ready for Post-2015 MDG Development Agenda?-Situation Analysis}

A situation analysis as seen in Table 3 reveals how North Africa and Sub-Saharan Africa (SSA) before 2012 are positioned in terms of being on track or not. While Table 4 on a broader scale attempts explain Sub-Regions and Countries that will likely achieve the MDGs. In July 2012, the report, published by the United Nations Economic Commission for Africa (ECA), African Union, African Development Bank (AfDB) and the United Nations Development Programme (UNDP), was considered and endorsed at the 19th Summit of African Union Heads of State and Government held in Ethiopia. The report observed that Africa has effectively engaged in the process of defining the contours of the post-2015 development agenda as deadline for the Millennium Development Goal (MDG) target draws near. 
Table 2. Some of the specific strategies proposed for accelerating achievement of the MDGs during the five years covered by the Countdown Strategy.

\begin{tabular}{|c|c|}
\hline Specific goal & Strategy for accelerating achievement \\
\hline $\begin{array}{l}\text { MDG 1: Eradicate extreme } \\
\text { poverty and hunger }\end{array}$ & $\begin{array}{l}\text { Accelerate the growth of the economy, ensure a stable macroeconomic environment, } \\
\text { address infrastructure gaps, ensure an enabling environment for a market-based, } \\
\text { private sector driven economy, and ensure pro-poor economic policies. }\end{array}$ \\
\hline $\begin{array}{l}\text { MDG 2: Achieve universal } \\
\text { primary education }\end{array}$ & $\begin{array}{l}\text { Ensure training of an adequate number of teachers and continuous teacher re-training as } \\
\text { a priority. Provide more classrooms to address the shortfall in school infrastructure. }\end{array}$ \\
\hline $\begin{array}{l}\text { MDG 3: Promote gender equality } \\
\text { and empower women }\end{array}$ & $\begin{array}{l}\text { Implement the National Gender Policy effectively through sector budgets, legislation and } \\
\text { clear policy directives (guidelines, incentives and sanctions) on mainstreaming gender in } \\
\text { both federal and state ministries, departments and agencies. Accelerate implementation of the } \\
\text { Beijing Platform for Action to ensure at least } 35 \text { per cent of political posts are filled by women. }\end{array}$ \\
\hline MDG 4: Reduce child mortality & $\begin{array}{l}\text { Rapidly implement the Integrated Maternal, Newborn and Child Health Care Strategy } \\
\text { using the Ward Minimum Health Package. }\end{array}$ \\
\hline MDG 5: Improve maternal health & $\begin{array}{l}\text { Strengthen the primary health care system at local level and ensure the implementation } \\
\text { of the Safe Motherhood Programme. }\end{array}$ \\
\hline $\begin{array}{l}\text { MDG 6: Combat HIV/AIDS, } \\
\text { malaria and other diseases }\end{array}$ & $\begin{array}{l}\text { Rapidly adopt and effectively implement the new National HIV/AIDS Strategic Framework } \\
\text { for Action 2010-2015. Reinforce the implementation of an integrated approach to malaria } \\
\text { control, tuberculosis and neglected tropical diseases (NTDs). }\end{array}$ \\
\hline $\begin{array}{l}\text { MDG 7: Ensure environmental } \\
\text { sustainability }\end{array}$ & $\begin{array}{l}\text { Implement integrated National Environmental Action Plans that address climate change. } \\
\text { Scale up the coverage of access to potable water and sanitation facilities. }\end{array}$ \\
\hline $\begin{array}{l}\text { MDG 8: Develop a global } \\
\text { partnership for development }\end{array}$ & $\begin{array}{l}\text { Promote the fulfilment of the G8 Gleneagles commitments, the Doha Development Round } \\
\text { and the Copenhagen Accord. Strengthen the G20, D8 and NEPAD in initiatives } \\
\text { to encourage foreign direct investment. }\end{array}$ \\
\hline
\end{tabular}

Table 3. Some of the MDGs at a glance: status of North Africa and Sub-Saharan Africa (SSA) before 2012.

\begin{tabular}{|c|c|c|}
\hline Goals and targets & North Africa & Sub-Saharan Africa \\
\hline \multicolumn{3}{|l|}{ G1 Poverty } \\
\hline T.1 Halve Poverty & On track & Not on track \\
\hline T.2 Reduce extreme hunger by half & On track, minimal change & Not on track, minimal change \\
\hline \multicolumn{3}{|l|}{ G2 Primary Education } \\
\hline T.3 Achieve Universal Primary education & Met & Progress, but lagging \\
\hline \multicolumn{3}{|l|}{ G3 Gender Equality } \\
\hline T.4 Empowerment of Women & On track, minimal change & Not on track, minimal change \\
\hline T.5 Eliminate Gender Disparity all levels of education by 2015 & On track, minimal change & Not on track, minimal change \\
\hline $\begin{array}{l}\text { T.6 More women have a voice and representation } \\
\text { in public policy and decision-making process }\end{array}$ & On track, minimal change & Not on track, minimal change \\
\hline T.7 Women have improved job prospects & On track, minimal change & Not on track, minimal change \\
\hline \multicolumn{3}{|l|}{ G4 Child mortality } \\
\hline T.8 Reduce under 5 mortality by two thirds & Met & Not on track, minimal change \\
\hline T.9 Measles immunization (85\%) of population at risk & Met & Not on track, minimal change \\
\hline
\end{tabular}

G5 Maternal mortality

T.10 Reduce maternal mortality by two thirds

On track, likely to achieve goal Lagging, unlikely to achieve target

Source: Barcelona Development Agenda (2004) [sic]. 
Table 4. Sub-regions and countries that will likely achieve the MDGs.

\begin{tabular}{|c|c|c|}
\hline Goals & Sub-regions likely to achieve the goal & Countries \\
\hline $\begin{array}{l}\text { Goal 1: Eradicate extreme } \\
\text { poverty and hunger }\end{array}$ & $\begin{array}{l}\text { North Africa except Sudan } \\
\text { and Mauritania }\end{array}$ & Not specified \\
\hline $\begin{array}{l}\text { Goal 2: Achieve universal } \\
\text { primary education }\end{array}$ & $\begin{array}{l}\text { North Africa except Sudan } \\
\text { and Mauritania }\end{array}$ & Not specified \\
\hline Goal 3: Promote gender equality & $\begin{array}{l}\text { Central Africa, West Africa, } \\
\text { North Africa, Part of South Africa }\end{array}$ & Not specified \\
\hline Goal 4: Reduce child mortality & North Africa & Mauritius, Seychelles and Cape Verde \\
\hline Goal 5: Improve maternal mortality & North Africa & Mauritius, Seychelles and Cape Verde \\
\hline $\begin{array}{l}\text { Goal 6: Combat HIV/AIDS, } \\
\text { malaria and other diseases }\end{array}$ & North Africa & $\begin{array}{l}\text { HIV/AIDS: Botswana and Zimbabwe. Malaria: Gambia, } \\
\text { Guinea-Bissau, Comoros, Benin, Rwanda, Central Africa, } \\
\text { Cameron and Kenya. Tuberculosis: Zambia, Angola, Gabon, } \\
\text { Gambia, Madagascar, South Africa and Swaziland. }\end{array}$ \\
\hline $\begin{array}{l}\text { Goal 7: Ensure environmental } \\
\text { sustainability }\end{array}$ & $\begin{array}{l}\text { All sub-region, access to } \\
\text { safe water in urban areas }\end{array}$ & $\begin{array}{l}\text { Environment: Swaziland, Gambia and Cape Verde. } \\
\text { Rural water: Burundi, Malawi, Botswana, Tanzania, Ghana } \\
\text { and Namibia. Urban sanitation: Ghana and Mauritius. }\end{array}$ \\
\hline
\end{tabular}

Source: $\underline{w w w . d e v e l o p m e n t g o a l s . o r g ~(U n i t e d ~ N a t i o n s ~ d a t a b a s e-O E C D / D A C) . ~}$

The report, “Assessing Progress in Africa towards the Millennium Development Goals 2012”, explains ongoing efforts to capture emerging perspectives from Africa on the post-2015 development agenda, but urges countries in the region to remain focused on the MDG targets. However, the report stressed that "these efforts must, however, not detract African countries from the focus on making continued progress toward achieving goals by the 2015 target date" [21].

The report therefore suggests a post-2015 agenda that seeks to promote the resilience of African countries to socio-economic and climate-related shocks by addressing associated vulnerabilities. "The post 2015 development agenda must reflect an appropriate balance of development enablers and outcomes”, it says, arguing that the MDGs have focused largely on development outcomes and less on the means or processes required to achieve the goals $\cdots$ (it) must provide broad indications of development enablers while taking note of country and regional specificities”, the report explains.

The report said important enablers for the development of African countries should include enhanced peace and security; good governance; human rights for all; strengthened access to justice and equality; a credible participatory process; and enhanced capacity to measure progress and ensure accountability [21].

\section{Conclusions}

In conclusion I believe that the collaboration between governments and civil society and other relevant stakeholders is crucial in creating the necessary synergy to ensure that we achieve the Millennium Development Goals (MDGs) over the next two years and define economic priorities and strategies in a way that works for the majority of our citizens.

However, it is vital to note that on MDGs 2, 3, 4, 6 and 8 relating to universal primary education, gender and women's empowerment, reducing child mortality, combating HIV/AIDS and other diseases, and global partnership for development, the lights show green and amber, according to the Nigeria’s 2010 MDGs Report. The report, however, admits an emphatic red light for goals 1, 5 and 7 on extreme poverty and hunger, maternal health and environmental sustainability.

To be fair, there has been good progress on some of the goals. There has been an amazing effort by the MDGs Office at the Presidency to channel debt relief gains into poverty-reducing projects across the country. Despite teething challenges, the Conditional Grants Scheme (CGS) which makes funds available to states and local governments for use on locally identified pro-poor priorities has been hugely successful in delivering social infrastructure, strengthening the partnership between the three tiers of government and improving public expenditure practices in some ways [22]. 
However, the MDG Report of 2012 clearly observed that Official Development Assistance (ODA) in Africa's development is important, but African policymakers are urged to diversify their portfolio of such funding so as to maximize the volume of resources and minimize exposure to funding shocks. In addition, promoting African products' access to global markets provides an opportunity for growing out of aid. Trade is vital for Africa's development, and the continued growth of Aid for Trade (AfT) commitments, which are growing faster than ODA, are welcomed. Still, AfT's concentration in a few countries is a concern that requires an immediate remedy.

\subsection{Prognosis}

Nigeria is a country of enormous diversity. The country's zonal and regional differences and disparities are traced to history, culture, natural endowment and politics. These, in turn, have resulted in poverty reduction challenges that are peculiar to some regions and zones and not others and that manifest themselves in different intensities in different, regions, zones, states, and communities. Consequently, a one-size-fits-all set of MDGsinspired interventions and investments is likely to miss the goals and targets. The enormous diversity among the different regions, zones, states, and communities in Nigeria with respect to their specific conditions, institutions, culture, and governance structures, implies that accelerated progress on the MDGs will depend on the unique conditions, opportunities and constraints of each of these component parts. No single roadmap will be adequate.

This paper attempts not only to identify the policy constraints and bottlenecks specific to each of the prevailing Nigerian micro-contexts, it also highlights those strategies, policies, programmes and projects that have had demonstrable impacts on improving the ability of the poor to climb and stay out of poverty in each context. Furthermore, it attempts to identify key areas where policy coherence and harmonization is required if progress towards MDGs achievements is to be accelerated. However, experience with policy design and implementation in Nigeria teaches us that policy gains can always be reversed. Consequently, the achievements towards the MDGs identified in this study, do not necessarily imply that they will maintained and sustained. The emerging development challenges described above bring new risks, which can have lasting impacts on poverty patterns in the country. Future measures to accelerate MDGs progress as 2015 approaches need to be accompanied by measures to maintain, augment and protect the achievements already realized. Slow GDP growth on the continent (3\% on average in the $90 \mathrm{~s}$ ) has made reaching the MDGs difficult. There is a growth deficit of over $4 \%$ to halve poverty. The need to indicate pro- poor growth that disproportionally benefits the poor is crucial. Attaining MDGs 2-8 is dependent among other things on converting commitment to actions both by donors and African States [23].

\subsection{Policy Directions}

Synergies across MDGs allows for some degrees of freedom in the choice of policy instruments. Increasing growth and decreasing income inequality are essential characteristics of any poverty reduction strategy in Africa. The relative emphasis on growth and inequality is country-specific. The pace of economic growth as well as the state of income distribution in Africa is determined by structural factors. These include institutional factors that determine the quality of governance, as well as geography and economic structures. Increasing agricultural productivity, managing population growth, and addressing spatial distribution of poverty within African economies are crucial policy areas.

Sub-Saharan Africa depends on three components for a successful drive to reach the MDGs: Commitment, Contextualization, and Institutional Capacity. Commitment—Pledges made and the mutual accountability of such pledges are important. In this respect a joint study by ECA/OECD to ensure greater aid effectiveness is being undertaken. Contextualization-Countries have started to integrate the MDGs into their national development frameworks (PRSPs) and have tailored them to their national circumstances (examples Rwanda, Tanzania, Senegal, Zimbabwe, Ethiopia). Institutional Capacity-here, the development of a capable state that maintains peace and security, creates a very conducive environment for the private sector and delivers public goods efficiently is critical. This also entails building statistical capacity for effective monitoring of development results.

In sum, accelerating progress to achieve the MDGs will require an integrated approach that takes into account the inter-linkages among goals and indicators. Yet it is not enough to reach the MDGs-progress must be kept up after that to make a difference to the lives of ordinary people. That momentum will require policymakers to ensure equal access to basic social services without compromising such services' quality. Sustainability also hinges on the capacity of African countries to continue providing critical services such as Antiretroviral Therapy and other essential drugs, even without vertical funds. Ultimately, African countries will have to transform their 
economies in ways that not only support rapid and inclusive growth but also generate enough domestic resources to offset shortfalls in external financing [3].

\section{References}

[1] (2010) Remarks of President Barack Obama during Millennium Development Goals Summit United Nations Headquarters New York, New York. The White House Office of the Press Secretary September 22.

[2] Iwuamadi, C.K. (2010) EPAD and the Challenges of Millennium Development Goals in Africa in the $21^{\text {st }}$ Century: A Critical Analysis of Modernization Prescription on Africa’s Development. Lambert Academic Publishing, Germany.

[3] MDG 2012 Report (2012) Assessing Progress in Africa toward the Millennium Development Goals: MDG Report 2012. Emerging Perspectives from Africa on the Post-2015 Development Agenda. Published by Economic Commission African for Africa, African Development Bank Group, UNDP, and Africa Union.

[4] (2011) World Bank Report.

[5] Ezehi, M. and Wasah, C. (2008) Learning Lessons: Monitoring and Evaluating Nigeria’s MDGs Expenditures. A Publication of Centre for Democracy and Development (CDD) \& Community Action for Popular Participation (CAPP), Abuja.

[6] Excerpts from ILO Website. www.ilo.org

[7] Krugman, P. (2009) Malign Neglect-The Return of Depression Economics and the Crisis of 2008. Norton, New York, 162-164.

[8] (2010) Poverty in Focus-The MDGs and beyond: Pro-Poor Policy in a Changing World. International Policy Centre for Inclusive Growth (IPC-IG), Poverty Practice, Bureau for Development Policy, UNDP, Number 19.

[9] (2014) The Millennium Development Goals and Poverty Reduction in Nigeria: Progress, Prospects and Policy Implications. A Research Publication of Center for Democracy and Development (CDD) Abuja, Nigeria.

[10] The Millennium Development Goals Report (2013) Sub-Saharan Africa Continues Steady Progress on Millennium Development Goals-Building on Impressive Strides on Health and Education, Accelerated Action Needed towards Anti-Poverty Targets. UN Department of Public Information, New York.

[11] Food and Agriculture Organization (FAO) (2012) Ten Central African Countries Agree to Improve Forest Monitoring. http://www.fao.org/news/story/en/item/153735/icode/

[12] United Nations (2012) The Millennium Development Goals Report 2012. Sales No. E.12.I.4.

[13] Economic and Social Council Economic Commission for Africa and African Union Commission (2013) Report on Progress in Achieving the Millennium Development Goals in Africa. A Publication of Economic and Social Council Economic Commission for Africa and African Union Commission, Abidjan.

[14] United Nations, Office of the High Representative for the Least Developed Countries, and Locked Developing Countries and Small Island Developing States (UN-OHRLLS) (2012) Report of the 11th Annual Ministerial Meeting of Landlocked Developing Countries. United Nations Headquarters, New York, September 2012.

[15] WHO (2012) Trends in Maternal Mortality: 1990 to 2010. Geneva.

[16] Center for Democracy and Development (CDD) (2014) The Millennium Development Goals and Poverty Reduction in Nigeria: Progress, Prospects and Policy Implications. A Research Publication of Center for Democracy and Development (CDD), Abuja.

[17] Mailafia, O., Ojowu, O., Kwanashie, M. and Ibrahim, J. (2008) Vision 20-2020 and Nigeria’s Poverty Eradication Strategy: Defining the Appropriate Policy Agenda. Draft Memorandum to the Federal Government.

[18] Culled from the Publication. Nigeria MDGs: Countdown Strategy of Nigeria (2010-2015). www.mdgs.gov.ng

[19] SPARC (2010) Assessment of the Links between Conditional Grant Scheme Activities and State Reform Efforts. State Programme for Accountability, Responsiveness and Capability, Abuja.

[20] Nigeria Millennium Development Goals (MDGs): Countdown Strategy 2010 to 2015. A Publication of OSSAP-MDG Abuja, 2010. www.mdgs.gov.ng

[21] Quandzie, E. (2012) Africa Ready for Post-2015 MDG Development Agenda. Report. http://www.ghanabusinessnews.com/africa-ready-for-post-2015-mdg-development-agenda-report/

[22] Bolton, T. (2011) Facing the Issue. Article in the Next Newspaper.

[23] Center for Democracy and Development (CDD) (2014) The Millennium Development Goals and Poverty Reduction in Nigeria: Progress, Prospects and Policy Implications. A Research Publication of Center for Democracy and Development (CDD), Abuja. 